\begin{tabular}{|l|l|l||}
\hline \multicolumn{2}{|c|}{ PublisherInfo } \\
\hline \hline PublisherName & $:$ & BioMed Central \\
\hline \hline PublisherLocation & $:$ & London \\
\hline \hline PublisherImprintName & $:$ & BioMed Central \\
\hline \hline
\end{tabular}

\title{
Daughters keep to themselves
}

\begin{tabular}{|l|l|l||}
\hline \multicolumn{2}{|c|}{ ArticleInfo } \\
\hline \hline ArticleID & $:$ & 3801 \\
\hline \hline ArticleDOI & $:$ & $10.1186 /$ gb-spotlight-20001018-01 \\
\hline \hline ArticleCitationID & $:$ & spotlight-20001018-01 \\
\hline \hline ArticleSequenceNumber & $:$ & 238 \\
\hline \hline ArticleCategory & $:$ & Research news \\
\hline \hline ArticleFirstPage & $:$ & 1 \\
\hline \hline ArticleLastPage & $:$ & 2 \\
\hline \hline & & RegistrationDate : 2000-10-18 \\
ArticleHistory & $:$ & OnlineDate \\
\hline \hline ArticleCopyright & $:$ & BioMed Central Ltd2000-10-18 \\
\hline \hline ArticleGrants & $:$ & \\
\hline \hline ArticleContext & $:$ & 130591111 \\
\hline \hline
\end{tabular}


In the 13 October Science Takizawa et al. use array analysis to identify a transmembrane protein that, combined with a septin barrier, may keep proteins in the daughter cells of budding yeast (Science 2000, 290:341-344). The messenger RNA for transcription factor Ash $1 \mathrm{p}$ is already known to be transported to the bud tip of the daughter yeast cell by an actomyosin system; once the protein is translated in the daughter cell it represses mating-type switching. Takizawa et al. look for other transported RNAs by immunoprecipitating tagged versions of the known transport proteins and analyzing bound RNAs with a whole-genome array. The RNA for the transmembrane protein Ist2p (increased sodium tolerance) is enriched, and localized to the bud tip. The protein is localized to the bud plasma membrane, and moves freely within this membrane. Ist2p spreads to the mother cell plasma membrane only upon loss of septin function. The septin neck filaments may form a barrier at the plasma membrane themselves, or recruit other proteins to form a barrier. Association with Ist2p, meanwhile, may restrict certain cytoplasmic proteins to the daughter cell.

\section{References}

1. Science, [http://www.sciencemag.org/]

2. Identification of asymmetrically localized determinant, Ash1p, required for lineage-specific transcription of the yeast $\mathrm{HO}$ gene.

3. Localization of ASH1 mRNA particles in living yeast. 